\title{
軽量鉄骨下地間仕切壁の面外静 的加力実験
}

\section{ANTI-PLANE STATIC LOADING TESTS ON PARTITION WALLS WITH LIGHT- GAUGE STEEL}

\begin{tabular}{|c|c|}
\hline 田中栄次 —— 1 & 寺田岳彦 \\
\hline 櫻庭記彦 —* 1 & 内本英雄 \\
\hline 小川雄一郎——* 1 & 室田文男 \\
\hline
\end{tabular}

キーワード :

非構造部材，間仕切壁，軽量鉄骨

Keywords:

Nonstructural component, Partition wall, Light-gauge steel

\author{
Eiji TANAKA — $* 1$ \\ Fumihiko SAKURABA $-* 1$ \\ Yuichiro OGAWA — $* 1$
}

A significant amount of research on Tohoku earthquake in 2011 reported the damages to nonstructural components. However, the survey on structural characteristics and seismic performance of nonstructural partition wall is scarce. In this paper, we carried out anti-plane static loading tests on partition walls with light-gauge steel and confirmed their behaviors and strength. In addition, their dynamic properties were estimated based on the results.

\section{1. 序}

2011 年の東北地方太平洋沖地震では天井の脱落をはじめ非構造部

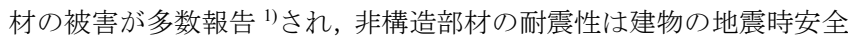
性を確保するために重要であるということが改めて認識された。特に, 大型の軽量鉄骨下地間仕切壁（以下 LGS 壁）が脱落した場合の被害 は甚大と予想され，上記地震時では写真 1 に示寸 LGS 壁の破損がみ られた。既往の研究 ${ }^{23)}$ では LGS 壁の面内構造性能を実験的に検証し ているが，面外方向の特性に関する研究事例 ${ }^{4}$ は極めて少ない。そこ で，本報では LGS 壁の面外方向静的加力試験を実施し，破壊性状・ 耐力等の構造力学特性調查及び而震性の検討を行う。

\section{2. 試験計画}

代表的な試験体を図 1 に，試験体諸元を表 1 に，使用部材を表 2 に各々示す。試験体は施工の現状を鑑みて全長やボード枚数等のパラ メータを設定し，実際と同一の部材 (JIS 規格品)・工法により試験場 所で製作した。通常の施工ではスタッドが壁全長より若干短いため, 上側想定ランナー（壁を鉛直に立てた場合上側を想定した方）とスタ ッドとの取合いにクリアランスを設ける。試験体 L2 では角形鋼管の 骨組 (以下補強鉄骨) を軽量鉄骨下地に追加した場合の補強効果を検 証する。試験体 L4，L5，M1〜M3 は北側ランナーが溝形鋼（以下 $\mathrm{C}$ 鋼受）を介して試験フレームに接続され，天井等と取合う端部剛性の 低い壁を模擬する。試験装置概要を図 2 に示す。試験は実大の試験体 を水平に設置し, 両端固定のもとジャッキにより面外方向に静的加力 するものである。尚, 製作時から加力直前まで試験体はサポートで支 持され，ほぼ水平な状態を保つ。中央のジャッキ及び加力治具により 加力点は試験体のほぼ $1 / 4$ 点に設定し, 地震時慣性力による等分布荷 重での最大曲げモーメントと端部せん断力を近似する。載荷計画を図 3 及び表 3 に示す。中央加力は荷重制御による正負交番の繰り返し載 荷とし，1２ サイクル毎に荷重振幅を増大させて耐力低下まで加力 を行う。尚, 荷重振幅の原点は $0(\mathrm{G})$ 相当, つまり試験体の自重を中 央ジャッキが支持した状態とする。さらに層間変形の影響を確認する ため, 試験体 L5 では南端部に設置したスライダーとジャッキを用い
て強制層間変形を与える。層間変 形入力は中央加力 $0(\mathrm{G})$ を維持し つつ行い, その後層間変形を固定 した状態で中央を加力するもの とし,層間変形角は中央加力の荷 重振幅に応じて増大させる。
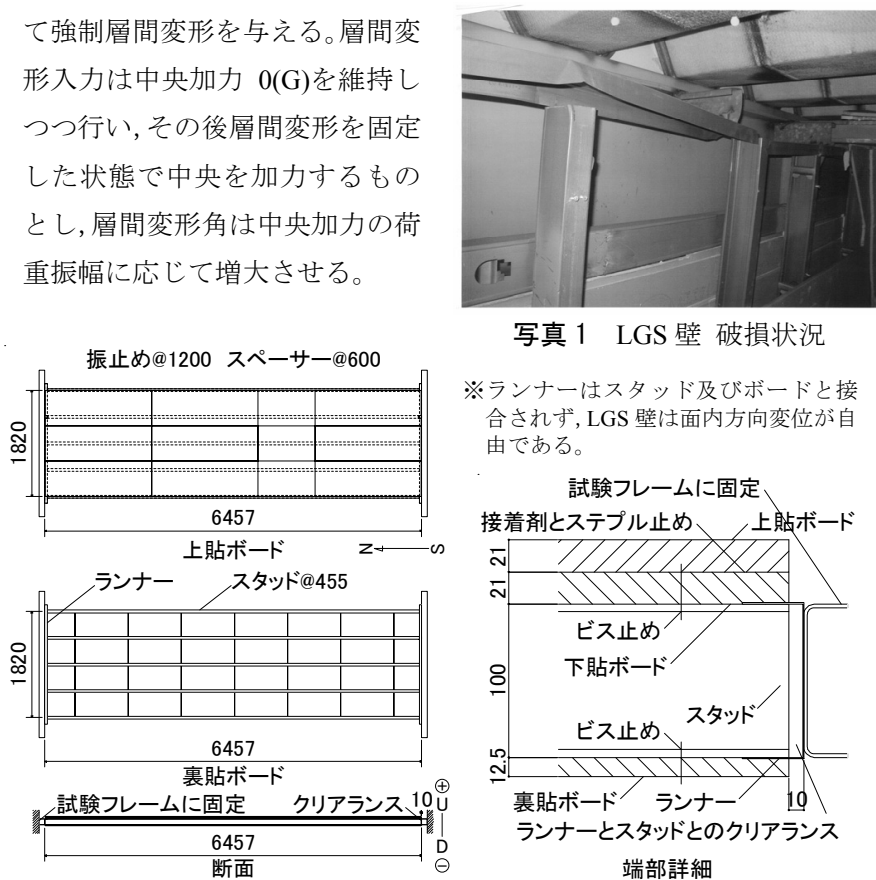

写真 1 LGS 壁 破損状況

※ランナーはスタッド及びボードと接 合されず, LGS 壁は面内方向変位が自 由である。

試験フレームに固定
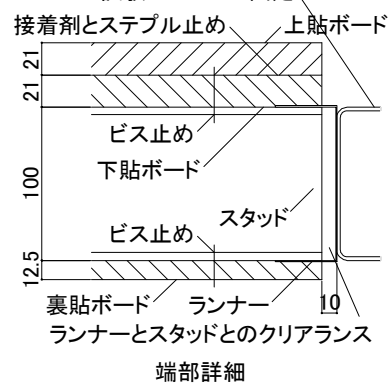

(a) 試験体 L3

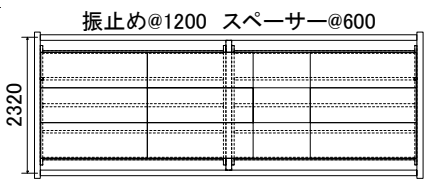

上貼ボード Z
補強鉄骨

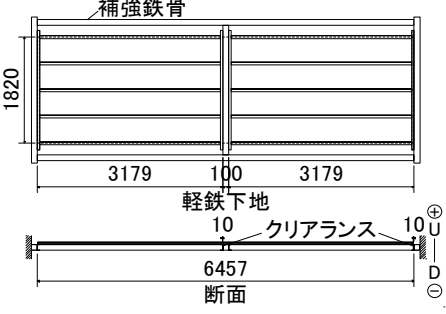

(b) 試験体 L2

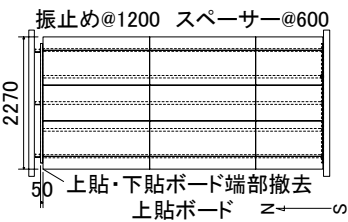

300 裏貼ボード端部撤去

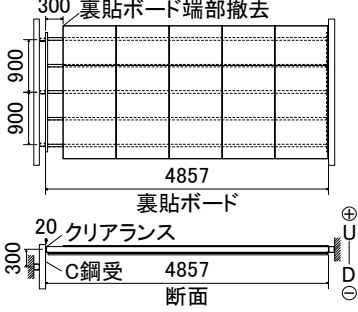

(c) 試験体 M3
図 1 試験体 
表 1 試験体諸元及び試験結果

\begin{tabular}{|c|c|c|c|c|c|c|c|c|c|c|c|c|c|c|c|c|c|c|c|c|c|}
\hline \multirow[b]{2}{*}{$\begin{array}{l}\text { 試 } \\
\text { 験 } \\
\text { 体 }\end{array}$} & \multirow[b]{2}{*}{$\begin{array}{c}\text { 幅 } \\
(\mathrm{mm})\end{array}$} & \multirow[b]{2}{*}{$\begin{array}{c}\text { 全長 } \\
l \\
(\mathrm{~mm})\end{array}$} & \multirow[b]{2}{*}{$\begin{array}{c}\text { 重量 } \\
W \\
(\mathrm{~kg})\end{array}$} & \multicolumn{2}{|c|}{ スタッド } & \multicolumn{3}{|c|}{$\begin{array}{l}\text { ボード厚 (mm) } \\
\end{array}$} & \multirow[b]{2}{*}{$\begin{array}{l}\text { 補 } \\
\text { 強 } \\
\text { 鉄 } \\
\text { 骨 }\end{array}$} & \multirow[b]{2}{*}{$\begin{array}{c}\text { C鋼 } \\
\text { 受 } \\
\text { 偏心 } \\
(\mathrm{mm})\end{array}$} & \multirow[b]{2}{*}{$\begin{array}{l}\text { 層 } \\
\text { 間 } \\
\text { 変 } \\
\text { 形 }\end{array}$} & \multirow{2}{*}{$\begin{array}{c}\text { 1) } \\
\text { クリア } \\
\text { ランス } \\
d \\
(\mathrm{~mm})\end{array}$} & \multirow{2}{*}{$\begin{array}{l}\text { 2) } \\
\text { 上 } \\
\text { 側 } \\
\text { 想 } \\
\text { 定 }\end{array}$} & \multirow[b]{2}{*}{$\begin{array}{c}\text { 北端 } \\
\text { ボード } \\
\text { 撒去 }\end{array}$} & \multirow[b]{2}{*}{$\begin{array}{l}\text { 上) } \\
\text { 貼 } \\
\text { 面 }\end{array}$} & \multicolumn{4}{|c|}{ 鉛直方向耐力 $P_{u}$} & \multicolumn{2}{|c|}{ 破壊性状 } \\
\hline & & & & $\begin{array}{c}\text { せい } \\
(\mathrm{mm})\end{array}$ & $\begin{array}{c}\text { 間隔 } \\
\text { @ } \\
(\mathrm{mm})\end{array}$ & $\begin{array}{l}\text { 上 } \\
\text { 貼 }\end{array}$ & $\begin{array}{c}\text { 下 } \\
\text { 貼 }\end{array}$ & $\begin{array}{l}\text { 裏 } \\
\text { 貼 }\end{array}$ & & & & & & & & $\begin{array}{c}\text { 上 } \\
\text { 方 } \\
\text { 向 } \\
(\mathrm{kN})\end{array}$ & $\begin{array}{c}\text { 下 } \\
\text { 方 } \\
\text { 向 } \\
(\mathrm{kN})\end{array}$ & $\begin{array}{l}\text { 上 } \\
\text { 方 } \\
\text { 向 } \\
\text { (G) }\end{array}$ & $\begin{array}{l}\text { 下 } \\
\text { 方 } \\
\text { 向 } \\
\text { (G) }\end{array}$ & $\begin{array}{c}\text { 上 } \\
\text { 方向 }\end{array}$ & $\begin{array}{c}\text { 下 } \\
\text { 方向 }\end{array}$ \\
\hline 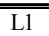 & 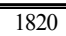 & 26457 & 2481 & (100 & 2606 & 221 & 21 & " - & - & " - & 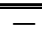 & $\overline{110}$ & " 南 & - & \begin{tabular}{c|} 
上面 \\
\end{tabular} & 2.9 & \begin{tabular}{l|l}
11.3 \\
\end{tabular} & 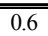 & $\begin{array}{l}2.4 \\
\end{array}$ & 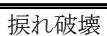 & " 局部破壊 \\
\hline L2 & 1820 & 6457 & 488 & 100 & 455 & 21 & 21 & - & 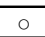 & - & - & 10 & 南 & - & 上面 & \begin{tabular}{|l|}
8.8 \\
\end{tabular} & 3.9 & 1.8 & 5.0 & 居孔破壊 & 局部破壊 \\
\hline L3 & 1820 & 6457 & 591 & 100 & 455 & 21 & 21 & 12.5 & - & - & - & 10 & 南 & - & 上面 & \begin{tabular}{|l|}
9.2 \\
\end{tabular} & 3.9 & 1.6 & 2.4 & 局部破壊 & 局部破壊 \\
\hline L4 & 1820 & 6457 & 489 & 00 & 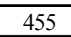 & 21 & 21 & - & - & 300 & - & 10 & 北 & - & 上面 & \begin{tabular}{|l|}
6.3 \\
\end{tabular} & \begin{tabular}{|l|}
11.0 \\
\end{tabular} & 1.3 & 2.3 & 据孔破壊 & 局部破壊 \\
\hline L5 & 2270 & 6457 & 722 & 100 & 455 & 21 & 21 & 12.5 & - & 300 & 0 & 20 & 北 & 裏貼 & 下面 & - & \begin{tabular}{|l|}
10.7 \\
\end{tabular} & - & 1.5 & - & 脱落 \\
\hline M1 & 2270 & 4857 & 541 & 100 & 455 & 21 & 21 & 12.5 & - & 300 & - & 20 & 北 & 裏貼 & 下面 & - & \begin{tabular}{|l|}
9.6 \\
\end{tabular} & - & 1.8 & - & 脱落 \\
\hline M2 & 2270 & 4857 & 541 & 100 & & 21 & 21 & 12.5 & - & 300 & - & 10 & 北 & 裏貼 & 下面 & \begin{tabular}{|l|}
17.0 \\
\end{tabular} & \begin{tabular}{|l|}
13.9 \\
\end{tabular} & 3.2 & 2.6 & 局部破壊 & 局部破壞 \\
\hline M3 & 2270 & 4857 & 538 & 100 & 455 & 21 & 21 & 12.5 & - & 300 & - & 20 & 北 & 全ボード & 下面 & - & \begin{tabular}{|l|}
9.9 \\
\end{tabular} & - & 1.9 & - & 脱落 \\
\hline S1 & 2270 & 4457 & 187 & 65 & 455 & 9.5 & 12.5 & - & - & - & - & 10 & 南 & - & 下面 & - & \begin{tabular}{|l|}
6.6 \\
\end{tabular} & - & 3.6 & - & 㨭れ破壊 \\
\hline S2 & 2270 & 4457 & 347 & 65 & 455 & 9.5 & 12.5 & - & - & - & - & 10 & 南 & - & 両面 & - & \begin{tabular}{|l|}
10.7 \\
\end{tabular} & - & 3.1 & - & 局部破壞 \\
\hline
\end{tabular}

2) 壁を鉛直に立てた場合上側を想定した方向を示寸

表 2 試験体使用部材

\begin{tabular}{|c|c|c|c|c|c|}
\hline \multirow{2}{*}{ 部材 } & \multirow{2}{*}{ 規格 } & \multicolumn{3}{|c|}{ 寸法 (mm) } & \multirow{2}{*}{$\begin{array}{c}\text { 使用 } \\
\text { 試験体 }\end{array}$} \\
\hline & & 幅 & せい & 厚さ & \\
\hline \multirow{2}{*}{ スタッド } & WS100 & 445 & 100 & 0.8 & $\begin{array}{l}\mathrm{S} 1 \cdot \mathrm{S} 2 \text { 以外 } \\
\end{array}$ \\
\hline & WS65 & 45 & 65 & 0.8 & $\mathrm{~S} 1 \cdot \mathrm{S} 2$ \\
\hline \multirow{2}{*}{ ランナー } & WR100 & 40 & 102 & 0.8 & $\mathrm{~S} 1 \cdot \mathrm{S} 2$ 以外 \\
\hline & WR65 & 40 & 67 & 0.8 & $\mathrm{~S} 1 \cdot \mathrm{S} 2$ \\
\hline \multirow{2}{*}{ スペーサー } & 100型 & - & - & 0.8 & $\mathrm{~S} 1 \cdot \mathrm{S} 2$ 以外 \\
\hline & 65型 & - & - & 0.8 & $\mathrm{~S} 1 \cdot \mathrm{S} 2$ \\
\hline 振止め & WB25 & 10 & 25 & 1.2 & 全て \\
\hline \multicolumn{2}{|c|}{ 補強鉄骨 (角形鋼管) } & 100 & 100 & 2.3 & L2 \\
\hline
\end{tabular}

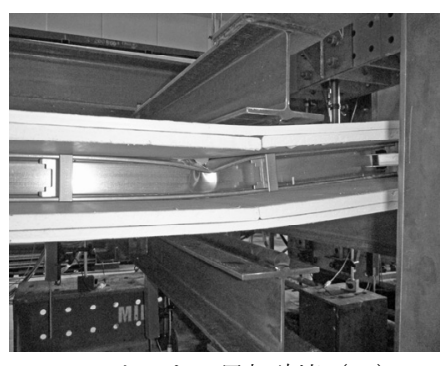

(a) スタッドの局部破壊（S2）

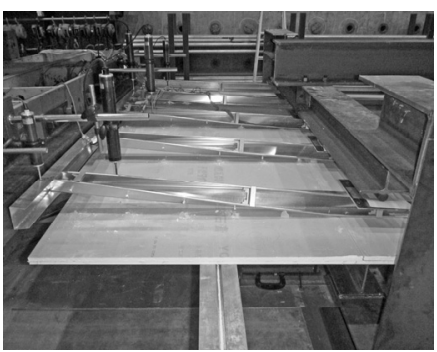

(c) 㧖れによるボード剥落（S1）

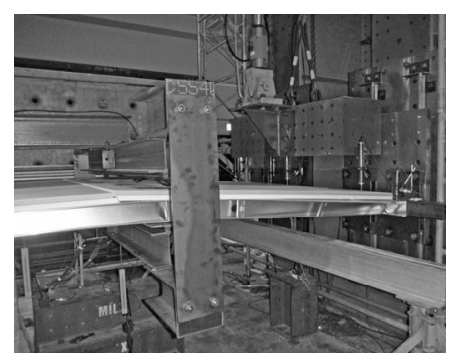

(b) スタッドの㧖れ破壊（L4）

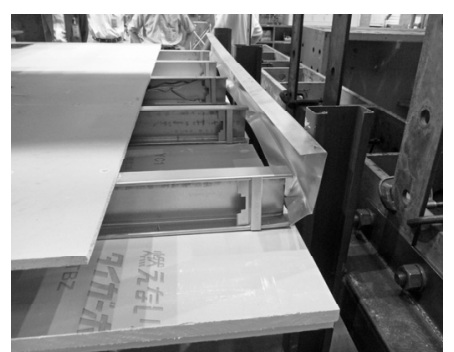

(d) ランナーからの脱落（M1）
写真 2 試験体 破壊性状

\section{3. 試験結果}

各試験体は鉛直上方向加力時と下方向加力時で異なる挙動・耐力を 示した。これは, ボードによるスタッドの拘束や, 試験体自重による 上方向と下方向加力でのモーメント分布の変化が影響していると考 えられ, 以降では各試験体について上方向加力と下方向加力時の試験 結果を個別に扱う。試験体の破壊性状は大別して写真 2 に示寸 3 種類 が観察された。最も多く観察された現象がスタッドの局部破壞であり， 曲げにより圧縮を受けるスタッドフランジがボードで拘束される場 合に, スタッド圧縮側フランジ・ウェブの局部変形を生じ耐力低下し た。破壊位置はモーメントが最大となる加力点付近または両加力点間 であり, 曲げに依存する破壞性状と考えられる。ボード片面貼りの試
表 3 載荷計画

\begin{tabular}{|c|c|c|c|}
\hline $\begin{array}{c}\text { 荷重 } \\
(\mathrm{G})\end{array}$ & サイクル数 & $\begin{array}{c}\text { 層間 } \\
\text { 変形角 }\end{array}$ & $\begin{array}{c}\text { 試験 } \\
\text { 体 }\end{array}$ \\
\hline \hline \pm 0.2 & 2 & 0 & 全て \\
\hline \pm 0.5 & 2 & $\mp 1 / 200$ & 全て \\
\hline \pm 0.8 & 2 & - & $\mathrm{S} 1$ \\
\hline \pm 1.0 & 2 & $\mp 1 / 100$ & 全て \\
\hline \pm 1.3 & 1 & - & $\mathrm{S} 1$ \\
\hline \pm 1.5 & $1(\mathrm{~L} 3$ の 2$)$ & $\mp 1 / 50$ & 全て \\
\hline \pm 2.0 & 1 & - & 全て \\
\hline $2.5 \sim$ & 1 & - & 全て \\
\hline
\end{tabular}
※層間変形入力は試験体 L5 のみ実施する

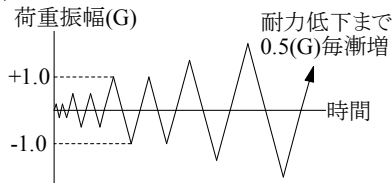

(a) 中央加力

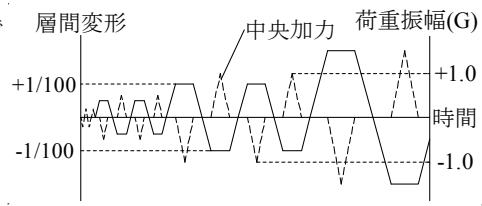

(b) 層間変形入力
図 3 載荷履歴概要

験体でスタッド圧縮側フランジにボードが貼られていない場合, スタ ッドの㧖れ変形が進展し横座屈やボードの剥落を生じた。ボードの剥 落はスタッドとボードとのビス止め接合部が㧖れモーメントにより 破壊するものである。スタッドの㧖れは試験体端部から加力点にかけ て生じたが,これは加力点で摩擦やてこ反力により㧖れ拘束されたた めであり, 実際の地震入力では LGS 壁全長に渡りスタッドが㧖れ変 形し, 試験結果と耐力や挙動は異なると推測される。ランナーとスタ ッドとのクリアランスが大きい試験体ではランナーからの脱落が観 察された。この際ランナ一は急激に変形し, 写真 1 に示す上部ランナ 一の破損に類似する状態となった。また, 多くの試験体においてボー ドの割れが耐力低下以前に引張側ボード継目で観察された。局部破壊 はこの割れに近い位置で生じることが多く, 厳密にはボード継目の局 所的な断面性能低下も挙動に影響を与えると考えられる。

表 1 に示す各試験体の耐力を比較すると, 脱落したものを除き総体 的に全長が短いほど耐力が増大する傾向が確認できる。よって, LGS 壁自体の破壊は曲げの影響を大きく受けることが示唆される。一方, 脱落した試験体の耐力は全長及びスタッド引張フランジ側ボードの 有無に依らず概ね一定であり, ランナーからの脱落は端部せん断力に 依存すると推測される。また, 据れによる破壊耐力は比較的低く, 試 験体 L1 は $1.0(\mathrm{G})$ 相当以下である。ボード両面貼りでは据れを生じな いが，石膏ボードは比強度・比剛性が低く, 試験体 S2 のようにボー ド枚数が多いと LGS 壁全体の比強度，つまり耐震性も低下し得る。 

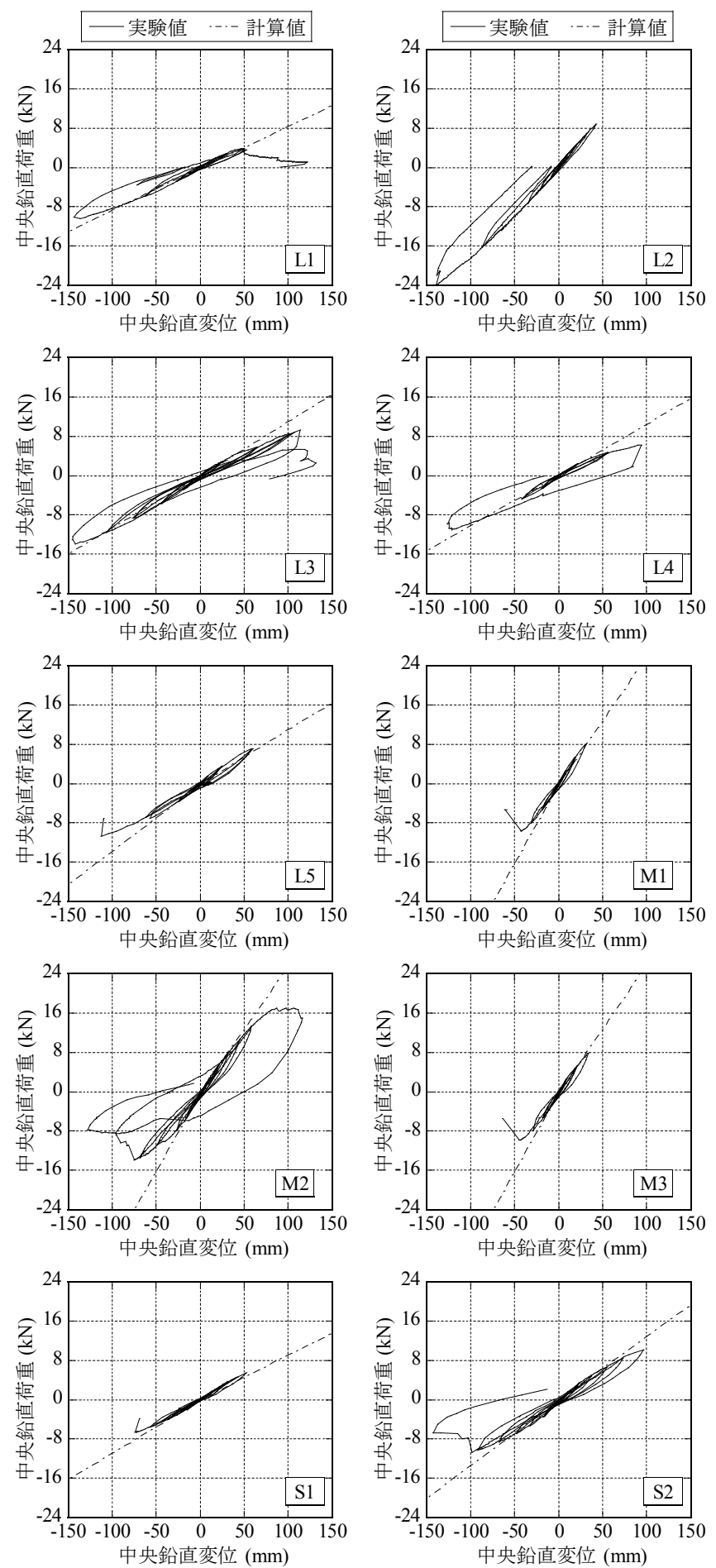

図 4 中央荷重一試験体中央変位関係

中央荷重一試験体中央鉛直変位関係を図 4 に示す。同図より, 各試 験体とも共通して非線形復元力特性を有し, スリップ型に近い性状と なることが分かる。スタッドの両フランジ歪から算出した曲率分布を 図 5 に示寸。曲率分布をモーメント分布として捉えると, 各試験体と も両端部で曲率が概齐ゼロに近付いており, LGS 壁の面外方向端部 境界条件は単純支持に近いことが確認できる。試験体 L2 は中央補強 鉄骨のランナーでも曲率がほぼゼロであるため, 補強鉄骨を追加する ことで LGS 壁は全長が分割された応力状態になり，補強鉄骨の耐力 や動的特性による応答増幅を無視寸れば分割数に応じて耐力は増大
※試験体 L1 は未計測，L3 は計測不備のため省略する

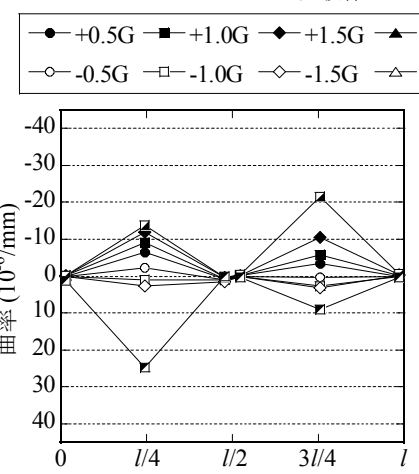

(a) 試験体 L2

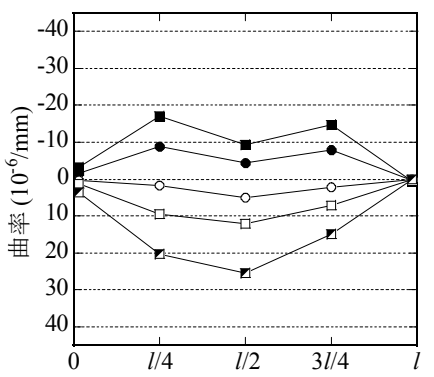

(c) 試験体 L5

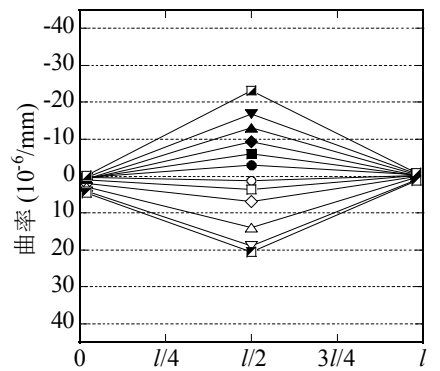

(e) 試験体 M2

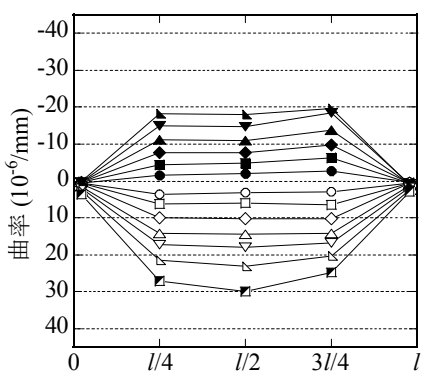

(g) 試験体 S1

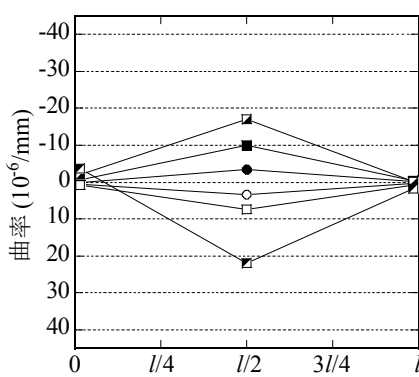

(b) 試験体 L4

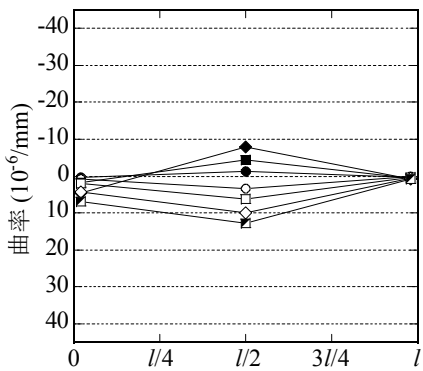

(d) 試験体 M1

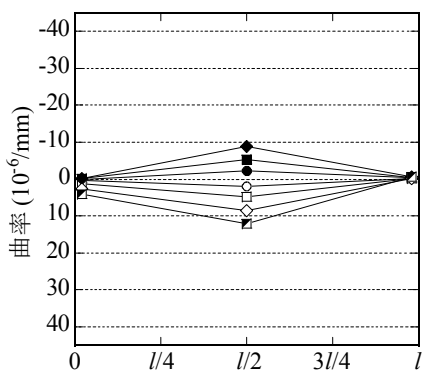

(f) 試験体 M3

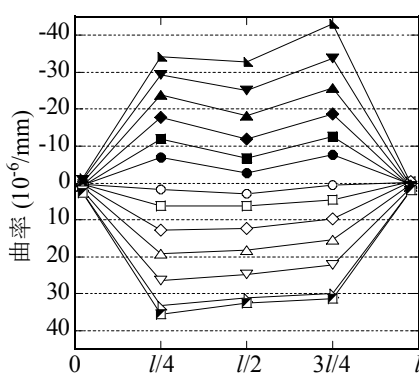

(h) 試験体 S2

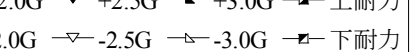

図 5 曲率分布

すると推測される。また，試験体 L5 は層間変形の影響がみられず, 単純支持に近いため層間変形が応力状態や耐力に影響しないと考え られる。同様に, 試験体 L4, L5, M1〜M3 で行った端部剛性の変化 もその動的特性による応答増幅を除けば影響はないと思われる。

\section{LGS 壁の耐力評価}

\section{1. LGS 壁の曲げ挙動及び局部破壊耐力評価}

以降は補強鉄骨のない基本的な壁仕様について, 実挙動と実験結果 が異なる可能性の高い㧖れによる破壊を除いて検討する。まず，LGS 壁の曲げ挙動を複合材料による合成断面の単純支持はりとしてモデ ル化する。等価曲げ岡性は次式で与えられる。

$$
E_{e q} I_{e q}=\sum E_{i}\left(I_{i}+A_{i} y_{i}^{2}\right)
$$


ここで, $E_{i}$ : 各材 (スタッド及び各石膏ボード) の圧縮・引張弾性率, $A_{i}$ : 各材の断面積, $I_{i}$ : 各材の断面二次モーメント, $y_{i}$ : 各材の図心か ら合成断面の中立軸までの距離である。スタッドのヤング率は 205000(N/ $\left.\mathrm{mm}^{2}\right)$ とし, 石膏ボードの復元力特性は非線形だが, 材料試 験を基に表 4 の值を圧縮・引張弾性率として各々定めた。図 4 に示寸 荷重一変形関係の等価曲げ剛性計算值と実験值とを比較すると, 非線 形性が顕著な領域では過大評価となるものの, 概社傾向を捉えている といえる。次に, スタッドの局部破壊がスタッド圧縮側フランジの局 部座屈に起因すると仮定して耐力評価する。局部座屈強度は圧縮側つ ランジがボードに拘束されていることを考慮し, 3 辺固定支持一辺自 由の圧縮板に近似して定める。その終局強度は文献 ${ }^{5)}$ 上り

$$
\begin{aligned}
& \frac{\sigma_{u}}{\sigma_{y}}= \begin{cases}1 & (R \leq 0.5) \\
0.571(R-0.5)^{2}-1.010(R-0.5)+1.0 & (R>0.5)\end{cases} \\
& R=\frac{b_{s}}{\pi t_{s}} \sqrt{\frac{12\left(1-v^{2}\right)}{k}} \sqrt{\frac{\sigma_{y}}{E_{s}}}, \quad k=\frac{4}{\alpha^{2}}+\frac{40}{3 \pi^{2}}+\frac{15 \alpha^{2}}{\pi^{4}}-\frac{20 v}{\pi^{2}}
\end{aligned}
$$

で与えられる。ここで, $\sigma_{u}$ : 終局強度, $\sigma_{y}=341\left(\mathrm{~N} / \mathrm{mm}^{2}\right)$ : スタッド降 伏強度材料試験值, $b_{s}$ : 板幅, $t_{s}$ : 板厚, $v=0.3$ : ポアソン比, $E_{s}=$ $205000\left(\mathrm{~N} / \mathrm{mm}^{2}\right)$ : ヤング率, $\alpha$ : 縦横比である。縦横比は座屈係数が 最小值 $k=2.31$ となる $\alpha=2.26$ （板の長さ $102(\mathrm{~mm})$ 相当）とする。得ら れた終局強度を用いて試験体の局部破壊耐力は次式で求められる。

$$
P_{u}= \pm \frac{8 E_{e q} I_{e q}}{E_{s} y_{s}^{\prime} l} \sigma_{u}+\left\{4 \frac{x}{l}\left(1-\frac{x}{l}\right)-1\right\} W \quad\left(\frac{1}{4} l \leq x \leq \frac{3}{4} l\right)
$$

ここで, $y_{s}^{\prime}$ : 合成断面の中立軸から圧縮フランジまでの距離， $x$ : 破 壊位置 (試験体北端を原点と寸る),$W$ : 試験体自重, $l$ : 全長である。 局部破壊耐力の計算值と実験值との比較を図 6 に示寸。同図より, 両 者は概ね整合しており，局部破壊耐力評価として有効と考えられる。

\section{2. ランナーからの脱落耐力評価}

本試験結果においてスタッド引張フランジ側のボードは耐力に影 響しないため, ボードを無視しランナーの曲げ耐力のみで脱落を表現 する。図 7 に示すように, スタッドと接触するランナーの板を集中荷 重下の片持はりと見做し, 板が全長に渡り全塑性に至る時点を脱落と 仮定する。このとき試験体の脱落耐力は次式で与えられる。

$$
P_{u}=2 \frac{\sigma_{y}^{\prime} Z_{p}}{d}=\frac{\sigma_{y}^{\prime} w_{r} t_{r}{ }^{2}}{2 d}
$$

ここで, $\sigma_{y}^{\prime}=302\left(\mathrm{~N} / \mathrm{mm}^{2}\right)$ : ランナー降伏強度材料試験值, $d:$ ランナ 一とスタッドとのクリアランス, $w_{r}$ : ランナー全長, $t_{r}$ : 板厚である。 $w_{r}=2000(\mathrm{~mm})$ として上式より脱落耐力を算出すると $9.65(\mathrm{kN})$ となり, 実験值 $10(\mathrm{kN})$ 前後と概袮合寸るため, 今後種々のパラメータによ る検討を行うことで脱落現象を模擬し得ると考えられる。

\section{5. 動的特性の推定}

LGS 壁の動的特性を前述した合成断面の単純支持はりとしてモデ ル化する。断面の回転慣性・せん断変形・減衰及び試駼結果の履歴特 性を無視した振動方程式及び固有振動数は次式で表される。

$$
\begin{aligned}
& E_{e q} I_{e q} \frac{\partial^{4} \delta(x, t)}{\partial x^{4}}+\frac{W}{l} \frac{\partial^{2} \delta(x, t)}{\partial t^{2}}=-\frac{W}{l} \ddot{y}(t) \\
& f_{j}=\frac{j^{2} \pi}{2} \sqrt{\frac{E_{e q} I_{e q}}{W l^{3}}} \quad(j=1,2, \cdots)
\end{aligned}
$$

ここで, $j:$ モード次数, $\delta$ : 変位, $x$ : 変位位置, $t$ : 時間, $y$ : 地動変 位である。上式より求めた試験体の 1 次固有振動数を表 5 に示す。同
表 4 石亮ボード設定弾性率

\begin{tabular}{|c|c|c|c|}
\hline \multirow{2}{*}{$\begin{array}{c}\text { 材厚 } \\
(\mathrm{mm})\end{array}$} & \multirow{2}{*}{ 方向 } & \multicolumn{2}{|c|}{ 弾性率 $\left(\mathrm{N} / \mathrm{mm}^{2}\right)$} \\
\cline { 3 - 4 } & & 圧縮 & 引張 \\
\hline \hline \multirow{2}{*}{21} & 平行 & 490 & 809 \\
\cline { 2 - 4 } & 直交 & 227 & 165 \\
\hline \multirow{2}{*}{12.5} & 平行 & 311 & 809 \\
\cline { 2 - 4 } & 直交 & 194 & 165 \\
\hline \multirow{2}{*}{9.5} & 平行 & 311 & 776 \\
\cline { 2 - 4 } & 直交 & 194 & 769 \\
\hline \multirow{2}{*}{$*$ 方は母材長辺方向に対して示- }
\end{tabular}

表 5 推定固有振動数

\begin{tabular}{|c|c|c|}
\hline \multirow{2}{*}{ 試験体 } & \multicolumn{2}{|c|}{ 1次固有振動数 $(\mathrm{Hz})$} \\
\cline { 2 - 3 } & 上方向 & 下方向 \\
\hline \hline $\mathrm{L} 1$ & 2.67 & 2.50 \\
\hline $\mathrm{L} 3$ & 2.65 & 2.48 \\
\hline $\mathrm{L} 4$ & 2.85 & 2.67 \\
\hline $\mathrm{L} 5$ & 2.34 & 2.51 \\
\hline $\mathrm{M} 1$ & 4.14 & 4.45 \\
\hline $\mathrm{M} 2$ & 4.14 & 4.45 \\
\hline $\mathrm{M} 3$ & 4.15 & 4.47 \\
\hline $\mathrm{S} 1$ & 4.16 & 4.49 \\
\hline $\mathrm{S} 2$ & 3.65 & 3.65 \\
\hline
\end{tabular}

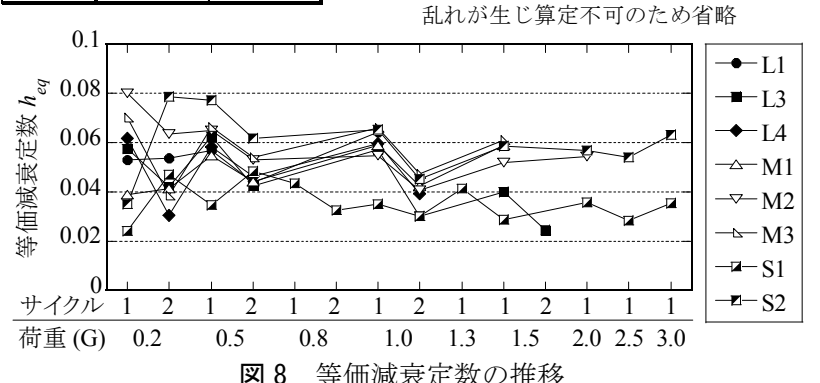

※凡例の上・下は各々上・下方向

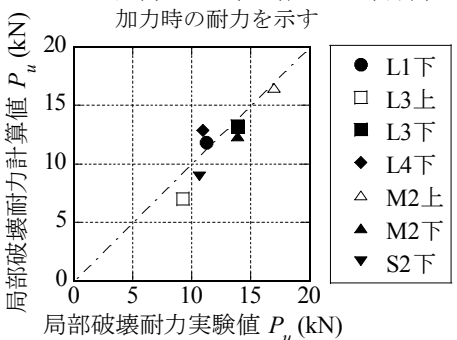

図 6 局部破壊耐力比較

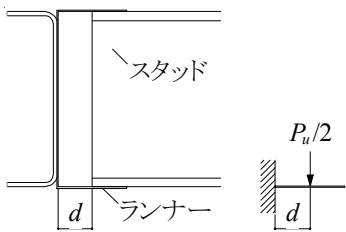

図 7 ランナーからの脱落モデル化

※試験体 L5 は層間変形入力で履歴に 乱れが生じ算定不可のため省略
表より, 各試験体の固有振動数は概ね 2〜 4.5(Hz)であり，一般的な中 低層建物において LGS 壁は共振する可能性があると判断できる。各 試験体を互いに比較すると, 全体として全長に対する依存性が大きく, また石膏ボードは重量に比して剛性が低いため, ボード枚数が多いほ ど長周期化する傾向がみられる。次に, LGS 壁の減衰推定として

$$
h_{e q}=\Delta W / 4 \pi W_{e}
$$

で定義される試験体の等価減衰定数 ${ }^{6}$ を図 8 に示す。ここで, $\Delta W$ : 履歴ループ吸収エネルギー, $W_{e}$ : 最大変位点割線剛性の弾性エネル ギーである。同図より, LGS 壁の減衰性能は履歷に依存するものの 2 〜 $6(\%)$ 程度期待できると考えられる。

\section{6. 結}

LGS 壁の面外方向静的加力試験を実施し, その力学的挙動及び而 力を検証した。さらに LGS 壁の力学特性をモデル化することで耐力 評価手法の提案及び動的特性の推定を行った。

\section{参考文献}

1) 日本建築学会：2011 年東北地方太平洋沖地震災害調査速報, AIJ, 2011

2) 田村 他：軽量鉄骨下地間仕切壁の静的加力実験，日本建築学会大会学術講 演梗概集, A-1, pp.985-986, 2006

3) 加登 他 : 軽量鉄骨下地間仕切り壁の耐震性能と修復性の検証, 日本建築学 会構造系論文集, No.614,pp.139-146, 2007.4

4) 松岡 他：軽量鉄骨下地間仕切壁とそれに囲まれた鋼製下地天井の耐震性能, 日本建築学会構造系論文集, No.632,pp.1857-1864, 2008.10

5) 土木学会 : 座屈設計ガイドライン, 丸善, 2005

6) L.S. Jacobsen : Damping in Composite Structures, WCEE II, pp.1029-1044, 1960 [2011 年 10 月 20 日原稿受理 2012 年 1 月 10 日採用決定 $]$ 